\title{
PEANUT RESPONSE TO LIME AND MOLYBDENUM APPLICATION IN LOW PH SOILS $^{(1)}$
}

\author{
J . A. QUAGGIO(2), P. B. GALLO(2), C. OWINO-GERROH ${ }^{(3)}$, \\ M. F. ABREU ${ }^{(2)} \&$ H. CANTARELLA(2)
}

\begin{abstract}
SUMMARY
Liming acid soils is considered to assure the availability of Mo in crops. Additionally, in peanuts (Arachis hypogaea L.) the positive response to liming is associated to a better supply of $\mathrm{Ca}^{+2}$, Mo for the nitrogenase-complex activity, and other non-nitrogen fixing activities of the crop. This study was thus undertaken to assess the effect of lime, Mo, and the lime-Mo interaction on peanut crop, on an acid UItisol at the Mococa Experimental Station, Instituto Agronômico, São Paulo State, Brazil, from 1987 to 1990. A randomized complete block design with four replications, in a $4 \times 4$ factorial arrangement, was used in the study. The factors included four lime rates $\left(0,2,4\right.$, and $\left.6 \mathrm{t} \mathrm{ha}^{-1}\right)$ broadcast and incor porated into the soil, and $\mathrm{Mo}\left(0,100,200\right.$, and $\left.300 \mathrm{~g} \mathrm{ha}^{-1}\right)$ as $\left(\mathrm{NH}_{4}\right)_{2} \mathrm{MoO}_{4}$ applied as seed dressing. Lime was applied once at the beginning of the study while Mo was applied at every planting. Peanut seed cv 'tatu' was used. Significant increase in peanut kernel yield with liming was only evident in the absence of Mo, whereas the peanut response to Mo was observed in two out of the three harvests. A higher yield response ( $28 \%$ increase) was found when Mo was applied without liming. Soil molybdenum availability, as indicated by plant leaf analysis, increased significantly when lime was applied. Molybdenum fertilization led to higher leaf $\mathbf{N}$ content, which in turn increased peanut yield in treatments with smaller lime doses.
\end{abstract}

Index terms: Arachis hypogaea, liming, molybdenum, nitrogen fixation

(1) Recebido para publicação em junho de 2002 e aprovado em junho de 2004.

(2) Researcher; Instituto Agronômico - IAC. Caixa Postal 28, CEP 13001-970 Campinas (SP). Brazil. E-mail: quaggio@iac.sp.gov.br

(3) Soil Fertility Professor, Department of Horticulture, Maseno University, P.O. Box 333, Maseno, Kenya. 


\title{
RESUMO: RESPOSTA DO AMENDOIM À CALAGEM E AO MOLIBDÊNIO EM SOLO ÁCIDO
}

\begin{abstract}
A calagem em sol os ácidos tem sido considerada prática suficiente para garantir a disponibilidade de molibdênio para as culturas. Adicional mente, seu efeito positivo na cultura do amendoim tem sido associado ao mel hor fornecimento de cálcio, maior disponi bilidade de mol ibdêni o para o compl exo nitrogenase, e outros processos na planta não relaci onados com a fixação biol ógica deN. Essetrabal ho foi real izado, com vistas em estudar os efeitos de doses de calcário e de molibdênio e suas interações na cultura do amendoim, num Argissolo áci do da Estação Experimental de Mococa do I AC durantetrês safras (1987 a 1990). Foi empregado o del ineamento em blocos, com quatro repetições, num esquema fatorial $4 \times 4$. Os tratamentos constituíram das doses de $0,2,4$ e $6 \mathrm{t}^{\text {ha-1 }}$ decal cário calcinado e de 0, 100, 200 e $300 \mathrm{~g} \mathrm{ha}^{-1}$ de Mo, aplicadas como tratamento de sementes, na forma de molibdato deamônio. O calcário foi aplicado uma única vez no início do ensaio, enquanto o M o foi aplicado anual mente por ocasião do plantio. Foi uti lizado o amendoi $\mathrm{m}$ cv. Tatu. Houveresposta significativa da produção degrãos à calagem apenas na ausência de Mo, enquanto a resposta do amendoim ao Mo foi observada em duas das três safras estudadas. Foi encontrado um maior ganho de produção ( $28 \%$ ) quando o Mo foi aplicado na ausência decalagem. A disponibilidadede Mo no sol o, avaliada por meio da análisede fol has, aumentou significativamentecom a calagem. A apli cação deM o proporcionou mai or concentração de nitrogênio nas fol has, o que aumentou a produtividade do amendoim nos tratamentos com doses mais baixas de calcário.
\end{abstract}

Termos de indexação: Arachis hypogaea, cal agem, moli ibdênio, fixação de nitrogênio.

\section{INTRODUCTION}

Peanuts (Arachis hypogaea L.), a legume, is an important crop for oil production and also a protein source (Krishna, 1997). It is grown on many soil types including those that are highly weathered and acidic (Gascho et al., 1993). Studies in such soils suggest a deficiency of available molybdenum (Mo) (Adams et al., 1990). Molybdate is sorbed by the soil (Goldberg \& F orster, 1998); however, molybdate sorption is highly sensitive to the soil $\mathrm{pH}$ and decreases with increases in soil pH (Adams et al., 1990; Goldberg \& Forster, 1998). Therefore, liming is an effective means of increasing the available molybdenum in such soils (Rosolem \& Caires, 1998; Quaggio et al., 1998; Hodges et al., 1994).

Molybdenum is one of the micronutrients required for plant growth and development. It is essential for the reduction of nitrate in plants (Sedbeery et al., 1993). Symptoms of Mo deficiency have been characterized in many crops including peanuts (Sedbeery et al., 1993). More pronounced deficiencies have been observed under acid soil conditions (Adams et al., 1990).

Molybdenum, which constitutes part of the enzyme nitrogenase, is also essential for symbiotic nitrogen fixation; Mo deficiencies are therefore much more pronounced in legumes (Bailey \& Laidlaw, 1999). Since peanut is a legume, it is highly susceptible to Mo deficiency when grown in acidic soils. This affects its ability to nodulate and symbiotically fix atmospheric nitrogen (Simbajon \& Duque, 1987; Bailey \& Laidlaw, 1999). This study, therefore, investigated the effect of lime and molybdenum and their interaction on peanut yields on a low pH soil.

\section{MATERIAL AND METHODS}

The study was conducted over three consecutive years (1987/88, 1988/89, and 1989/90) on an acidic Ultisol of the Mococa Experimental Station, Instituto Agronômico, Mococa, São Paulo State, Brazil. The following analysis results described the original soil characteristics: $\mathrm{pH}_{\left(\mathrm{CaCl}_{2}\right)}$ 4.2; exchangeable $\mathrm{Ca}, \mathrm{Mg}$, and $\mathrm{K}$, in $\mathrm{mmol}_{\mathrm{C}} \mathrm{dm}^{-3}, 10,4$, and 2.1 respectively, and $21 \%$ soil basesaturation. A randomized complete block design with four replications in a $4 \times 4$ factorial arrangement was used in the study. The factors consisted of four limerates $\left(0,2,4\right.$, and $\left.6 \mathrm{t} \mathrm{ha}^{-1}\right)$ and molybdenum (0,100, 200, and $\left.300 \mathrm{~g} \mathrm{ha}^{-1}\right)$. Burnt dol omitic limestone ( $127 \% \mathrm{CaCO}_{3}$ equivalent) and ammonium molybdate $\left(\left(\mathrm{NH}_{4}\right)_{2} \mathrm{MOO}_{4}\right)$ were used as lime and molybdenum sources, respectively. The limetreatments were applied once at the beginning of the study by broadcasting and mixing with the topsoil (depth 0 to $5 \mathrm{~cm}$ ), before deep incorporation by ploughing to the depth of $30 \mathrm{~cm}$, three months prior to planting in 1987. The treatments were set up in plots of 6 rows of $6 \mathrm{~m}$ in a spacing of 0.6 by $0.1 \mathrm{~m}$ between and within the rows, respectively, and 
were maintained on the same plots throughout the study period. Basic fertilization (0-20-15 NPK formula at a rate of $400 \mathrm{~kg} \mathrm{ha}^{-1}$ ) was applied each year at planting to all plots.

One year after liming, 15 soil samples from the plough layer were randomly collected with auger, mixed, dried, ground, sieved ( $2 \mathrm{~mm})$, and used to evaluate the soil pH, phosphorus and organic carbon contents, exchangeable bases, and exchangeable acidity as described by Raij \& Quaggio (1983).

Leaf samples, composed by 100 leaves per plot, were taken every year at flowering by collecting the third leaf from the top. The samples were washed, dried at $35^{\circ} \mathrm{C}$, and ground prior to total nutrient content analyses according to methods described by Bataglia et al. (1983).

Certified peanut (Arachis hypogaea L.) cv. 'tatu' seeds were dressed with $0,2.8,5.6$, and $8.4 \mathrm{~g}$ $\left(\mathrm{NH}_{4}\right)_{2} \mathrm{MoO}_{4}$, respectively, per $1.200 \mathrm{~g}$ of seeds. The seeds were then inoculated with Bradyrhizobium sp in each study year. No nitrogen fertilizer was applied throughout the study period. Other agricultural practices recommended for growing peanuts in Brazil were observed.

The statistical analysis of evaluated variables were based on variance and regression analyses using the Minitab Statistics Program (Minitab, 2000).

\section{RESULTS AND DISCUSSIONS}

Soil chemical analyses one year after the application of lime and molybdenum showed that liming increased exchangeable $\mathrm{Ca}$ and $\mathrm{Mg}$ and the soil base saturation linearly, while the soil pH increased from 4.2 in control plots to 5.7 in the plot under the highest liming rate (Table 1 ).

The peanut yield increase due to liming was not statistically significant, but thelime-Mointeraction was significant in all studied harvests (Table 2 ). The response of peanut to lime was quite linear in absence of Mo. This could be more related to the increase of Mo availability than to soil acidity neutralization, because no response to liming was observed where the smallest rate of Mo was applied (Figure 1).

Molybdenum application without lime in 1988/ 89 and with lime in 1987/88 and 1989/90 significantly increased theyields. However, the applied Mo with or without lime increased the average yields significantly in any case. In absence of liming, the calculated maximum yield was obtained with $186 \mathrm{~g} \mathrm{ha}^{-1} \mathrm{Mo}$, corresponding to a $28 \%$ increase in relation to the plots without Mo. Peanut response to Mo was closely related $\left(\mathrm{R}^{2}=0.90^{* *}\right)$ to the increase in nitrogen fixation, evaluated by the concentration of this nutrient in the leaves (Figure 2). Molybdenum deficiency symptoms were

Table 1. The effect of lime and Mo and their interactions on the soil chemical characteristics one year after liming

\begin{tabular}{|c|c|c|c|c|c|c|c|c|c|c|}
\hline \multirow{2}{*}{ Lime rate } & \multirow{2}{*}{ Mo rate } & \multirow{2}{*}{$R$ esin $\mathbf{P}$} & \multirow{2}{*}{$\begin{array}{l}\text { Organic } \\
\text { matter }\end{array}$} & \multirow{2}{*}{$\begin{array}{c}\mathrm{pH} \\
\mathrm{CaCl}_{2}\end{array}$} & \multicolumn{3}{|c|}{ Exchangeable cations } & \multirow{2}{*}{$\mathbf{H}+\mathbf{A l}$} & \multirow{2}{*}{$\begin{array}{c}\text { Sum of } \\
\text { bases }\end{array}$} & \multirow{2}{*}{$\begin{array}{c}\text { Base } \\
\text { saturation }\end{array}$} \\
\hline & & & & & $\mathbf{K}$ & $\mathbf{C a}$ & $\mathbf{M g}$ & & & \\
\hline t ha-1 & g ha-1 & $\mathrm{mg} \mathrm{kg}^{-1}$ & $\mathrm{~g} \mathrm{~kg}^{-1}$ & & 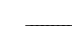 & 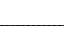 & $\mathrm{mol}_{\mathrm{c}} \mathrm{dn}$ & 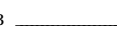 & - & $\%$ \\
\hline 0 & $\begin{array}{r}0 \\
100 \\
200 \\
300\end{array}$ & $\begin{array}{r}16 \\
9 \\
12 \\
12\end{array}$ & $\begin{array}{l}23 \\
22 \\
25 \\
22\end{array}$ & $\begin{array}{l}4.2 \\
4.3 \\
4.2 \\
4.2\end{array}$ & $\begin{array}{l}1.8 \\
1.6 \\
1.7 \\
1.8\end{array}$ & $\begin{array}{l}8 \\
8 \\
7 \\
7\end{array}$ & $\begin{array}{l}3 \\
3 \\
3 \\
3\end{array}$ & $\begin{array}{l}64 \\
62 \\
68 \\
64\end{array}$ & $\begin{array}{l}13 \\
13 \\
11 \\
12\end{array}$ & $\begin{array}{l}17 \\
17 \\
15 \\
16\end{array}$ \\
\hline 2 & $\begin{array}{r}0 \\
100 \\
200 \\
300\end{array}$ & $\begin{array}{l}14 \\
10 \\
12 \\
14\end{array}$ & $\begin{array}{l}25 \\
23 \\
26 \\
25\end{array}$ & $\begin{array}{l}4.8 \\
4.8 \\
4.6 \\
4.6\end{array}$ & $\begin{array}{l}1.4 \\
1.8 \\
1.7 \\
1.9\end{array}$ & $\begin{array}{l}14 \\
13 \\
13 \\
13\end{array}$ & $\begin{array}{l}8 \\
7 \\
6 \\
6\end{array}$ & $\begin{array}{l}45 \\
42 \\
51 \\
49\end{array}$ & $\begin{array}{l}23 \\
21 \\
21 \\
21\end{array}$ & $\begin{array}{l}35 \\
34 \\
29 \\
31\end{array}$ \\
\hline 4 & $\begin{array}{r}0 \\
100 \\
200 \\
300\end{array}$ & $\begin{array}{l}14 \\
11 \\
13 \\
12\end{array}$ & $\begin{array}{l}24 \\
24 \\
24 \\
24\end{array}$ & $\begin{array}{l}5.0 \\
5.2 \\
5.0 \\
5.1\end{array}$ & $\begin{array}{l}1.3 \\
1.6 \\
1.6 \\
1.5\end{array}$ & $\begin{array}{l}18 \\
17 \\
16 \\
15\end{array}$ & $\begin{array}{l}8 \\
9 \\
9 \\
9\end{array}$ & $\begin{array}{l}36 \\
35 \\
39 \\
38\end{array}$ & $\begin{array}{l}27 \\
28 \\
26 \\
26\end{array}$ & $\begin{array}{l}43 \\
44 \\
40 \\
41\end{array}$ \\
\hline 6 & $\begin{array}{r}0 \\
100 \\
200 \\
300\end{array}$ & $\begin{array}{l}14 \\
13 \\
16 \\
14\end{array}$ & $\begin{array}{l}26 \\
22 \\
25 \\
23\end{array}$ & $\begin{array}{l}5.6 \\
5.9 \\
5.5 \\
5.8\end{array}$ & $\begin{array}{l}1.3 \\
1.3 \\
1.7 \\
1.5\end{array}$ & $\begin{array}{l}22 \\
22 \\
22 \\
23\end{array}$ & $\begin{array}{l}12 \\
13 \\
12 \\
13\end{array}$ & $\begin{array}{l}31 \\
27 \\
32 \\
28\end{array}$ & $\begin{array}{l}36 \\
35 \\
36 \\
36\end{array}$ & $\begin{array}{l}54 \\
57 \\
51 \\
56\end{array}$ \\
\hline $\begin{array}{c}\text { F-test: } \\
\text { Lime }\end{array}$ & & ns & ns & $* * *$ & $* *$ & $* * *$ & $* * *$ & $* *$ & $* *$ & $* *$ \\
\hline Mo & & ns & ns & ns & ns & ns & ns & ns & ns & ns \\
\hline Lime $x$ Mo & & ns & ns & ns & ns & ns & ns & ns & ns & ns \\
\hline C.V. $(\%)$ & & 54 & 1 & 8 & 16 & 25 & 30 & 17 & 8 & 24 \\
\hline
\end{tabular}


Table 2. E ffect of lime and Mo and their interaction on peanuts yields

\begin{tabular}{|c|c|c|c|c|c|}
\hline \multirow{2}{*}{ Lime rate } & \multirow{2}{*}{ Mo rate } & \multicolumn{3}{|c|}{ Period } & \multirow{2}{*}{ Mean yiı } \\
\hline & & $87 / 88$ & $88 / 89$ & $89 / 90$ & \\
\hline $\mathrm{t} \mathrm{ha}^{-1}$ & $\mathrm{~g} \mathrm{ha}^{-1}$ & 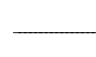 & $\mathrm{kg}$ & $\mathrm{ha}^{-1}$ & 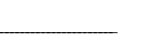 \\
\hline 0 & $\begin{array}{r}0 \\
100 \\
200 \\
300\end{array}$ & $\begin{array}{l}1855 \\
2163 \\
2113 \\
1723\end{array}$ & $\begin{array}{l}2075 \\
2633 \\
2660 \\
2948\end{array}$ & $\begin{array}{l}2188 \\
3073 \\
2990 \\
2820\end{array}$ & $\begin{array}{l}2039 \\
2623 \\
2588 \\
2497\end{array}$ \\
\hline $\begin{array}{l}\text { Mean } \\
2\end{array}$ & $\begin{array}{r}0 \\
100 \\
200 \\
300\end{array}$ & $\begin{array}{l}1963 \\
2107 \\
1770 \\
2435 \\
1635\end{array}$ & $\begin{array}{l}2579 \\
2218 \\
2453 \\
2393 \\
2665\end{array}$ & $\begin{array}{l}2768 \\
2515 \\
2723 \\
2676 \\
2800\end{array}$ & $\begin{array}{l}2437 \\
2280 \\
2315 \\
2501 \\
2367\end{array}$ \\
\hline $\begin{array}{l}\text { Mean } \\
\quad 4\end{array}$ & $\begin{array}{r}0 \\
100 \\
200 \\
300\end{array}$ & $\begin{array}{l}1987 \\
1733 \\
2143 \\
2323 \\
2308\end{array}$ & $\begin{array}{l}2432 \\
2605 \\
2535 \\
2688 \\
2632\end{array}$ & $\begin{array}{l}2678 \\
2888 \\
2538 \\
2853 \\
2678\end{array}$ & $\begin{array}{l}2366 \\
2409 \\
2405 \\
2621 \\
2540\end{array}$ \\
\hline $\begin{array}{l}\text { Mean } \\
6\end{array}$ & $\begin{array}{r}0 \\
100 \\
200 \\
300\end{array}$ & $\begin{array}{l}2126 \\
2453 \\
1895 \\
1770 \\
2018\end{array}$ & $\begin{array}{l}2615 \\
2310 \\
2753 \\
2633 \\
2598\end{array}$ & $\begin{array}{l}2739 \\
2953 \\
2830 \\
2828 \\
2873\end{array}$ & $\begin{array}{l}2494 \\
2572 \\
2493 \\
2410 \\
2496\end{array}$ \\
\hline Mean & & 2034 & 2573 & 2871 & 2492 \\
\hline $\begin{array}{l}\text { F-test: } \\
\text { Lime }\end{array}$ & & ns & ns & ns & ns \\
\hline $\begin{array}{c}\text { Mo } \\
\text { Lime } x \text { Mo }\end{array}$ & & $\begin{array}{l}\text { ns } \\
* *\end{array}$ & $\begin{array}{c}* * \\
*\end{array}$ & $\begin{array}{r}* \\
* *\end{array}$ & $\begin{array}{r}* \\
* *\end{array}$ \\
\hline C.V. (\%) & & 15 & 11 & 9 & 7 \\
\hline
\end{tabular}

* and **: statistically significant at $\mathrm{P}<0.05$ and $\mathrm{P}<0.01$, respectively.

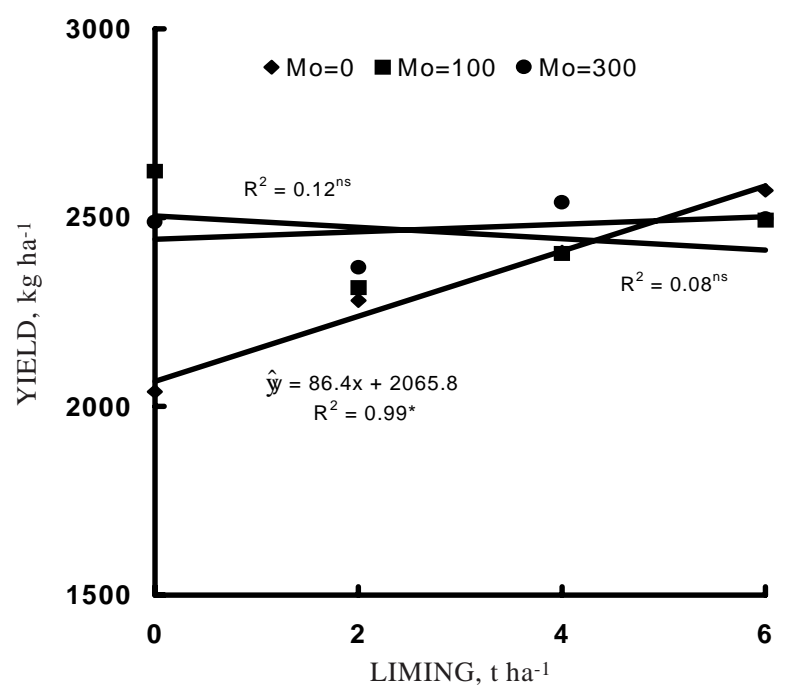

Figure 1. Lime and molybdenum interaction on peanut yield in low $\mathrm{pH}$ soil. Results of treatments with no lime application (averaged of three successive harvests). * and ns significant at 0.05 probability and non significant respectively.

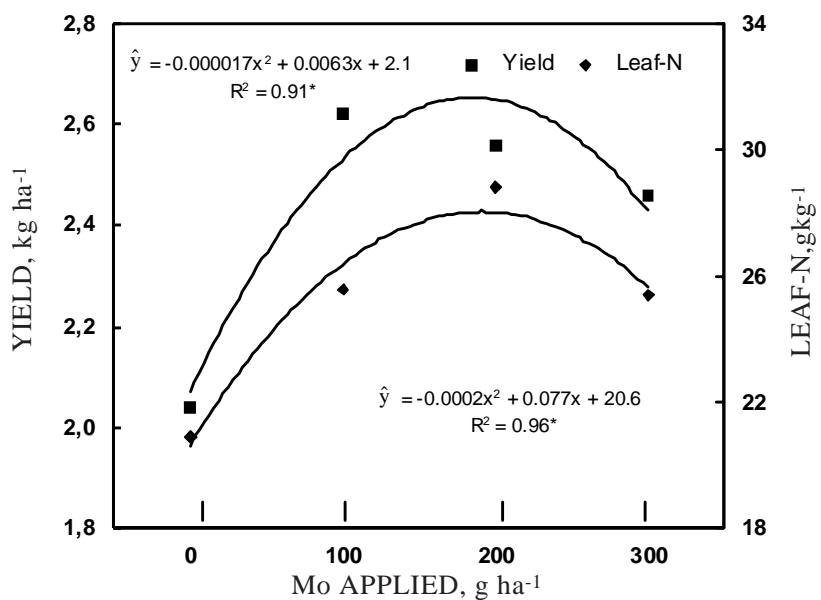

Figure 2. Effects of molybdenum rates on yield and nitrogen concentration in peanut leaves. Data of treatment without lime application. (Averaged results of three successive harvests) * significant at 0.05 probability.

only observed in control plots with a leaf Mo concentration around $2.0 \mathrm{mg} \mathrm{kg}^{-1}$. These symptoms were characterized by a general yellowing of the foliage and tip necrosis of the young leaves (Figure 4). These symptoms were earlier described as symptoms of Mn toxicity (Nakagawa et al, 1987), but they were not observed in plots with a leaf Mo higher than $3.0 \mathrm{mg} \mathrm{kg}^{-1}$, which was attained by both lime and molybdenum application.

Liming increased $\mathrm{Ca}$ and Mo significantly but decreased $\mathrm{Mn}$ and $\mathrm{Zn}$ contents in peanut leaves. Molybdenum applied with lime caused an increase in $\mathrm{N}$ and, without lime, an increase in $\mathrm{N}$ and in leaf Mo concentration (Table 3). A significant positive correlation was only found between the applied Mo and leaf $\mathrm{N}$ content. Leaf-N contents above $26 \mathrm{~g} \mathrm{~kg}^{-1}$ were associated with leaf Mo around $4.0 \mathrm{mg} \mathrm{kg}^{-1}$. However, at the highest leaf $\mathrm{N}$ contents leaf Mo tended to decrease due to dilution effects (F igure 3 ).

The effect of lime on peanut yield depends on many factors including the initial $\mathrm{Ca}$ and Mostatus of the soil, the time of lime application, and the peanut cultivar in use (Caires et al., 1991; Gascho et al., 1993; Hodges et al., 1994). Peanut cultivars with large seeds, as for example the Virginia and Valencia types, require considerably higher lime inputs to manifest any significant improvement in yields or grain quality. The results found in this study with soil liming are consistent with those of Rosolem \& Caires (1998) on a similar soil type in Brazil. The yield increase when Mo was applied without lime could be attributed to the increase in available Mo concentration in the soil. This enabled the plant to fix atmospheric nitrogen and also incorporate the nitrate taken up from the soil. This led to an increase of vegetative growth and consequently to higher kernel per pod yield. 
Table 3. Effect of lime, Mo and their interaction on peanut leaf nutrient content (Averaged results of three harvests)

\begin{tabular}{|c|c|c|c|c|c|c|c|c|c|c|c|c|}
\hline \multirow{2}{*}{ Lime rate } & \multirow{2}{*}{ Mo rate } & \multicolumn{11}{|c|}{ Foliar content } \\
\hline & & $\mathbf{N}$ & $\mathbf{P}$ & K & $\mathrm{Ca}$ & Mg & $\mathrm{Cu}$ & $\mathbf{F e}$ & Mn & Mo & Zn & Al \\
\hline t ha-1 & $\mathrm{g} \mathrm{ha-1}$ & 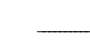 & 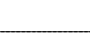 & $-g k g$ & 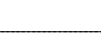 & $\underline{-}$ & 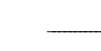 & 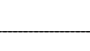 & $\mathrm{m}$ & $\mathrm{kg}^{-1}$ & 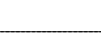 & 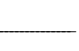 \\
\hline 0 & $\begin{array}{r}0 \\
100 \\
200 \\
300\end{array}$ & $\begin{array}{l}20.9 \\
25.6 \\
28.8 \\
25.4\end{array}$ & $\begin{array}{l}1.7 \\
1.6 \\
1.6 \\
1.5\end{array}$ & $\begin{array}{l}17.4 \\
18.4 \\
21.0 \\
19.9\end{array}$ & $\begin{array}{l}15.3 \\
14.1 \\
14.6 \\
12.1\end{array}$ & $\begin{array}{l}5.0 \\
5.1 \\
5.1 \\
4.9\end{array}$ & $\begin{array}{l}6.8 \\
8.7 \\
9.6 \\
8.3\end{array}$ & $\begin{array}{l}300 \\
418 \\
308 \\
369\end{array}$ & $\begin{array}{l}212 \\
223 \\
256 \\
243\end{array}$ & $\begin{array}{l}2.0 \\
3.0 \\
3.6 \\
2.7\end{array}$ & $\begin{array}{l}31.4 \\
30.4 \\
37.0 \\
31.0\end{array}$ & $\begin{array}{l}598 \\
807 \\
598 \\
750\end{array}$ \\
\hline 2 & $\begin{array}{r}0 \\
100 \\
200 \\
300\end{array}$ & $\begin{array}{l}23.7 \\
26.8 \\
25.5 \\
27.6\end{array}$ & $\begin{array}{l}1.9 \\
1.6 \\
1.7 \\
1.7\end{array}$ & $\begin{array}{l}18.4 \\
18.2 \\
19.5 \\
19.6\end{array}$ & $\begin{array}{l}16.8 \\
16.5 \\
12.8 \\
15.4\end{array}$ & $\begin{array}{l}6.4 \\
5.3 \\
5.0 \\
6.1\end{array}$ & $\begin{array}{l}8.2 \\
8.7 \\
8.3 \\
9.1\end{array}$ & $\begin{array}{l}371 \\
290 \\
373 \\
443\end{array}$ & $\begin{array}{l}189 \\
126 \\
142 \\
197\end{array}$ & $\begin{array}{l}3.4 \\
4.7 \\
4.7 \\
4.6\end{array}$ & $\begin{array}{l}33.1 \\
26.5 \\
25.3 \\
31.9\end{array}$ & $\begin{array}{l}782 \\
586 \\
763 \\
913\end{array}$ \\
\hline 4 & $\begin{array}{r}0 \\
100 \\
200 \\
300 \\
0 \\
100 \\
200 \\
300\end{array}$ & $\begin{array}{l}22.7 \\
28.9 \\
28.6 \\
27.4 \\
28.4 \\
30.4 \\
24.8 \\
26.2\end{array}$ & $\begin{array}{l}1.8 \\
1.6 \\
1.6 \\
1.6 \\
1.7 \\
1.6 \\
1.6 \\
1.7\end{array}$ & $\begin{array}{l}19.2 \\
18.3 \\
18.8 \\
17.8 \\
17.1 \\
20.0 \\
17.4 \\
18.3\end{array}$ & $\begin{array}{l}17.6 \\
16.1 \\
14.8 \\
13.9 \\
17.5 \\
17.8 \\
14.1 \\
15.0\end{array}$ & $\begin{array}{l}5.5 \\
5.4 \\
5.8 \\
5.3 \\
6.0 \\
5.9 \\
5.3 \\
6.2\end{array}$ & $\begin{array}{l}8.5 \\
8.2 \\
8.9 \\
8.5 \\
8.5 \\
9.1 \\
8.5 \\
8.8\end{array}$ & $\begin{array}{l}296 \\
441 \\
315 \\
311 \\
357 \\
324 \\
429 \\
370\end{array}$ & $\begin{array}{r}136 \\
71 \\
133 \\
119 \\
113 \\
88 \\
99 \\
133\end{array}$ & $\begin{array}{l}3.6 \\
3.6 \\
4.6 \\
4.1 \\
2.5 \\
3.7 \\
4.9 \\
4.1\end{array}$ & $\begin{array}{l}27.2 \\
21.8 \\
24.9 \\
30.1 \\
29.6 \\
21.4 \\
20.5 \\
25.5\end{array}$ & $\begin{array}{l}635 \\
895 \\
618 \\
629 \\
718 \\
643 \\
939 \\
776\end{array}$ \\
\hline F test: & & & & & & & & & & & & \\
\hline $\begin{array}{c}\text { Lime } \\
\text { Mo }\end{array}$ & & $\begin{array}{l}\mathrm{ns} \\
* *\end{array}$ & $\begin{array}{l}\text { ns } \\
\text { ns }\end{array}$ & $\begin{array}{l}\text { ns } \\
\text { ns }\end{array}$ & $\begin{array}{l}* * \\
* *\end{array}$ & $\begin{array}{l}\text { ns } \\
\text { ns }\end{array}$ & $\begin{array}{l}\text { ns } \\
\text { ns }\end{array}$ & $\begin{array}{l}\text { ns } \\
\text { ns }\end{array}$ & $\begin{array}{l}* * \\
*\end{array}$ & $\begin{array}{l}* \\
*\end{array}$ & $\begin{array}{r}* * \\
*\end{array}$ & $\begin{array}{l}\text { ns } \\
\text { ns }\end{array}$ \\
\hline Lime $x$ Mo & & $*$ & ns & ns & ns & ns & ns & ns & ns & ns & ns & ns \\
\hline C.V. (\%) & & 10.5 & 11.1 & 9.2 & 13.9 & 11.8 & 12.9 & 26.3 & 26.9 & 38.2 & 20.6 & 26.6 \\
\hline
\end{tabular}

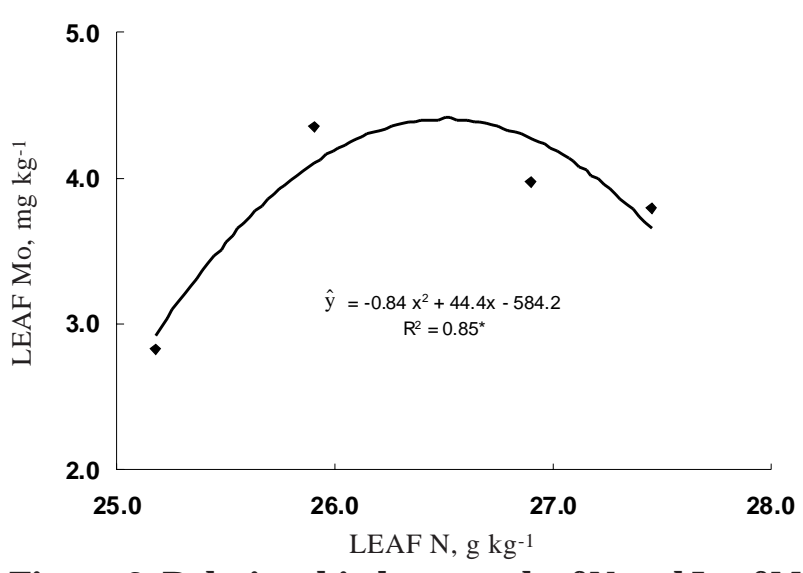

Figure 3. Relationship between leaf $\mathbf{N}$ and Leaf Mo in peanut crop established in four lime rates, averaged in three successive harvests. (Data for Mo rates were averaged) *significant at 0.05 probability.

In absence of liming, a significant quadratic relationship was found between leaf nitrogen content and the amount of Mo applied to the soil (Figure 2). Gascho et al. (1993), Sahu et al. (1998),

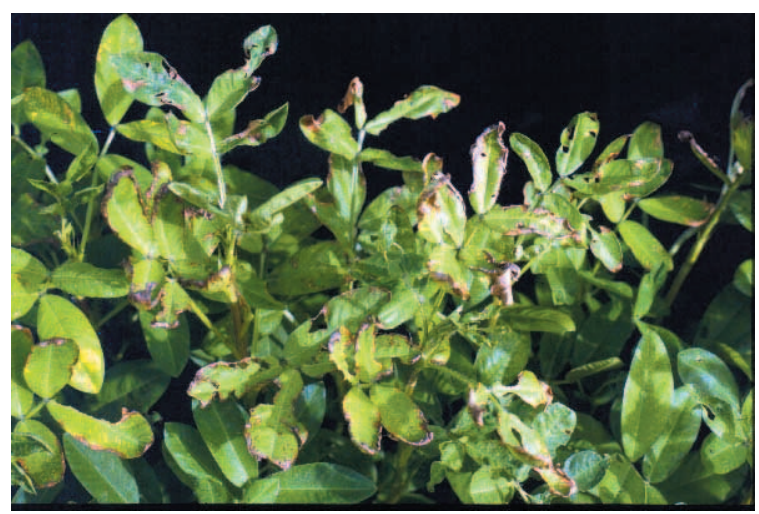

Figure 4. Molybdenum deficiency symptoms in peanut crop.

and Rosolem \& Caires (1998) al so found consistent results and attributed the increase in peanut yields to increased growth and development to Mo application. The yield increase when lime and Mo were applied could be explained by several reasons including that the increasing soil reaction increased available Mo, as a result of liming. The increase in soil Mo concentration due to liming is well documented (Goldberg \& F orster, 1998). 
The yield increase could also be related to an increased concentration of basic cations in the soil solution (Table 1), particularly $\mathrm{Ca}$, that could have complemented the effect of Mo on the nutrition of the peanut plant. Calcium plays a fundamental role in the peanut nutrition, especially at the pod devel opment; Ca deficiency at this stage would have a negative effect on yields (Hodges et al., 1994; Fernandez et al., 2000). The ameliorating effect of lime on $\mathrm{Al}$ and $\mathrm{Mn}$ toxicity and the increase in available N, P, and Mo could al so have contributed to the yield increase. These effects could have improved the soil conditions for plant growth (Table 1), and reduced theadsorption of the applied Mo to the soil. Sahu et al. (1995; 1998) studied peanut response to lime and Mo on acidic soil environment and furthermore observed that the yield increase was due to the increased efficiency of Mo associated to the lime application.

\section{CONCLUSIONS}

1. Although liming significantly reduced the soil acidity, its effect on peanut yields was only significant in absence of Mo.

2. The peanut yield was more limited by molybdenum deficiency than by soil acidity in this low pH soil.

3. In absence of lime, a seed-dressed Mo rate of $186 \mathrm{~g} \mathrm{ha}^{-1}$ produced maximum peanut yields.

4. The molybdenum rate for a maximum peanut yield decreased as the lime rate increased.

\section{ACKNOWLEDGMENTS}

Theauthors thank the CNPq (Consel ho Nacional de Desenvolvimento Científico e Tecnológico) and the Third World Academy of Science for research fellowship and support.

\section{LITERATURE CITED}

ADAMS, J .F.; BURMESTER, C.H., \& MITCHELL, C.C. Longterm fertility treatments and molybdenum availability. Fert. Res., 21:167-170, 1990.

BAILEY, R. \& LAIDLAW, L.R. The interactive effects of $P, K$, lime and molybdenum on the growth and morphology of white clover (Trifolium repens L.) at establishment. Grass Fol., 16:69-76, 1999.

BATAGLIA, O.C.; FURLANI A., M.C.; TEIXEIRA, J.P.F.; FURLANI, P.R. \& GALLO, J .R. Methods for leaf analyses. Campinas, Instituto Agronômico de Campinas, 1983. 48p. (Technical Bulletin, 78) (In Portuguese)
CAIRES, E.F.; ROSOLEM, C.A.; WRIGHT, R.J .; BALINGER, V.C. \& MURMANN, R.J. The root growth of peanut cultivars and soil acidity. In: PLANT AND SOIL INTERACTIONS AT LOW pH. INTERNATIONAL. SYMPOSIUM, 2., Beckley, 1991. Proceedings. Beckley, US. Development in Plant and Soil Science, 1991. p.239-243

FERNANDEZ, E.M.; ROSOLEM, C.A. \& OLIVEIRA, D.M.T. Peanut seed tegument affected by liming and drying method. Seed Sci. Technol., 28:185-192, 2000.

GASCHO, G.J .; HODGES, S.C.; ALVA, A.K.; CSINOS, A.S. \& MULLINEX J r., B.G. Calcium and time of application for Runner and Virginia peanut. Peanut Sci., 20:31-35, 1993.

GOLDBERG, S. \& FORSTER, H.S. Factors affecting molybdenum adsorption by soils and minerals. Soil Sci., 163:109-114, 1998.

HODGES, S.C.; GASCHO, G.S. \& KIDDER, G. Calcium and magnesium. In Research based on soil testing information and fertilizer recommendations for peanuts on Coastal Plain soils. Alabama, Auburn University, 1994. (Series Bull., 380)

KRISHNA, P.K. Phosphorus uptake and utilization efficiency in peanut. Peanut Sci., 24:1-6, 1997.

MINITAB Inc. User's guide 2: Data analysis and quality tools. Release 13 for Windows, 2000.

NAKAGAWA, J .; VILAS BOAS, R.L. \& HELIODORO, B. Toxidez de manganês em amendoim cv. Tatu (identificação do problema). R. Agric., 62:157-162, 1987.

QUAGGIO, J.A.; GALLO, P.B.; FURLANI, A.M.C.\& MASCARENHAS, H.A.A. Soybean and sorghum grain yields isopleths for liming and molybdenum rates. R. Bras. Ci. Solo, 22:337-344, 1998.

RAIJ , B. Van \& QUAGGIO, J .A. Métodos de analise química e de solo para fins de fertilidade. Campinas, Instituto Agronômico, 1983. 31p. (Boletim Técnico, 31)

ROSOLEM, C.A. \& CAIRES, E.E. Theyield and nitrogen uptake of peanuts as affected by Lime, cobalt and molybdenum. J . Plant Nutr., 21:827-835, 1998.

SAHU, S.K.; DHAL, J .K.; DAS, B.B. \& DAS, P.K. Response of groundnuts to boron with and without molybdenum and lime in a laterite soil. Inter. Arachis Newsl., 15:19-30, 1995.

SAHU, S.K.; KABAT, B. \& NAYAK, S.K. AvailableB, Mo, status on alluvial soil of Orissa growing groundnuts and its response Mo on laterite soils. Environ. Ecology. 16:772775, 1998.

SEDBEERY, J R.; DHARMAPUTRA, R.H.; BRUPBACHER, R.H.; PHILLIPS, S.A.; MARSHALL, J .G.; SLOANE, I.W.; MELVILLE, D.R.; ROBB, J .I. \& DAVIS, J .H. Molybdenum investigations with soybean in Louisiana. Louisiana, Louisiana State University, 1973. 39p. (Bulletin, 630)

SIMBAJ ON, E.C. \& DUQUE, C.M. Nodulation, N-fixation and yield of peanut (Arachis hypogaea L.) as influenced by inoculation and nitrogen fertilization on limed and unlimed strongly acid tropical soil. J . Agric. Food Nutr., 9:132-157, 1987. 